\title{
Performance of Raised Bed Irrigation in Comparison to AWD and Flood Irrigation for Boro Rice
}

\author{
S. M. I. Hossain \\ Department of Agricultural Engineering, Bangabandhu Sheikh Mujibur Rahman Agricultural University, \\ Bangladesh
}

\begin{abstract}
An experiment was conducted in Bangabandhu Sheikh Mujibur Rahman Agricultural University experimental farm to evaluate the performance of raised bed irrigation (RBI) system in comparison to alternate wetting and drying (AWD) and flood irrigation (FI) methods for Boro rice (BR 45) during 2012-2013. Four treatments: irrigation in raised bed two rows $\left(T_{1}\right)$, in raised bed three rows $\left(T_{2}\right)$, alternate wetting and drying $\left(T_{3}\right)$ and flood irrigation $\left(T_{4}\right)$ were considered for performance evaluation. The highest grain yield of 5.09 t/ha was produced in treatment $T_{3}$ (AWD) followed by treatment $T_{4}$ (FI) (4.77 t/ha), $T_{1}$ (RBI two rows) (4.69 t/ha) and $T_{2}$ (RBI three rows) $(3.91 \mathrm{t} / \mathrm{ha})$. The highest water productivity was obtained in treatment $T_{1}(66.41 \mathrm{~kg} / \mathrm{ha}-$ $\mathrm{cm})$ followed by treatment $T_{2}(58.33 \mathrm{~kg} / \mathrm{ha}-\mathrm{cm})$ and $T_{3}(48.77 \mathrm{~kg} / \mathrm{ha}-\mathrm{cm})$. The least amount of water required to produce one kilogram $(\mathrm{kg})$ of rice grain was in treatment $T_{1}(1556 \mathrm{l} / \mathrm{kg})$ while the highest was in treatment $T_{4}$ (2341 l/kg). Treatment $T_{1}$ (RBI two rows) and $T_{2}$ (RBI three rows) required $34 \%$ and $22 \%$ less water than the flood irrigation $\left(T_{4}\right)$. Therefore, raised bed irrigation can be adopted for Boro rice in water scarce areas.
\end{abstract}

Keywords: $A W D$, Boro rice, flood irrigation, Raised bed irrigation, water productivity

\section{Introduction}

Water is one of the major inputs for crop production. In the dry season, crops are grown through irrigation. Therefore, irrigation plays an important role in crop production that in turn ensures the food security. Water is becoming increasingly scarce worldwide [1]. Irrigation water is also becoming scarce in Bangladesh. With the raising of river and canal beds due to increase of siltation the surface water is being diminished gradually. In addition, surface water (river and canal water) is getting polluted by indiscriminate discharge of industrial effluents. For this reason, groundwater is becoming the major source of irrigation water for crop cultivation which is also depleting rapidly and becoming polluted by heavy metals like arsenic [2,3]. So it is high time to think about the efficient use of irrigation water. The raised bed irrigation for Boro rice can be an effective and proper practice for efficient use of irrigation water for Boro rice production in Bangladesh.

Boro rice is conventionally produced by flood irrigation method where water is applied in the plane rice field at a depth of 4 to $5 \mathrm{~cm}$. In this method it requires about 3000 to 5000 liters of water to produce one kilogram of rice [4]. In flood irrigation method exposed water surface allows the highest water loss through evaporation. But, in alternate wetting and drying (AWD) method, it has been reported to save more than $27 \%$ of irrigation water and provide higher yield than flood irrigation [5]. It is also reported that the AWD technology can reduce 5 numbers of irrigation compared to conventional flood irrigation and save irrigation water up to $25 \%$ [4]. Rice transplanted on furrow irrigated rice bed is comparable with traditional rice culture that can save as much as $25-50 \%$ irrigation water [6]. An increased grain yield of $17 \%$ was produced in bed planting with 70 $\mathrm{cm}$ bed width over conventional method when planted rice in rice-wheat cropping system [7].

Irrigation water in the rice field is used mainly in three ways: water uptakes by the plant through roots which is transpired by the leaves to the atmosphere, water evaporates from the soil surface to the atmosphere and water percolates to the groundwater provided runoff and seepage are properly controlled. Rate of percolation of water is fully controlled by the soil type and that is why there is limited human control over percolation. Water uptakes by the roots is the requirement of the plant and any controlled over the transpiration will hamper plant growth and reduce yield. So, it is essential to provide adequate water for optimum transpiration of plants. In raised bed irrigation there is a limited water surface area for evaporation, which can reduce evaporation loss of water from the irrigation field [8]. Therefore raised bed irrigation can reduce the irrigation water and consequently reduce the cost of irrigation. Hence to increase the water use efficiency and water productivity, it can be effective technology for rice [9].

In raised bed planting of rice, water from furrows flows horizontally to the root zone which reduces the percolation of water from the root and simultaneously decreases the loss of fertilizer with percolation water. This will increase the effective use of fertilizer. It will reduce the water loss through percolation as the percolation will mainly take place from the furrows. So, raised bed will reduce loss of water through percolation and evaporation, and fertilizer loss simultaneously. Thus permanent raised bed system can improve water and 
fertilizer use efficiency by $20-25$ percent and reduce the total production cost by about 30 percent [10]. Hence raised bed irrigation for Boro rice requires field trial to investigation its benefit over others.

The major part of the country's fresh water is being used in field crops cultivation, mainly rice. The irrigated area of field crops should be increased to produce more food grain for the increasing population of the country. This will require more water for irrigation. In the dry season, rice production in Bangladesh is practiced using conventional flood irrigation method and uses mostly groundwater due to scarcity of surface water. This has made a remarkable depletion of groundwater in the country. The conventional flood irrigation for Boro rice requires about 3000 to 5000 liters of water to produce one kilogram of rice. This can be reduced to about 2000 liters by adopting AWD method [11]. However, this needs to be further reduced to less than 2000 liters of water for one kilogram of rice. The raised bed irrigation can be an option to reduce the irrigation water to optimum level. Hence, the present research project was carried out to evaluate the performance of raised bed irrigation system in comparison to AWD and flood irrigation for Boro rice.

\section{Materials And Methods}

The study was conducted in the Bangabandhu Sheikh Mujibur Rahman Agricultural University experimental farm during Boro season in 2012-13. The experiment was laid in randomized complete block design (RCBD) with three replications. The unit experimental plot was $3 \times 4 \mathrm{~m}^{2}$ size and polythene paper was placed between two plots at a depth of $30 \mathrm{~cm}$ to protect seepage of water from one plot to others. In addition, 2 $\mathrm{m}$ fellow space was kept between the plots to minimize the seepage from one plot to others. Bed was prepared at a height of $5 \mathrm{~cm}$ from the ground surface and furrow depth was $10 \mathrm{~cm}$ from the ground surface. So, bed height was $15 \mathrm{~cm}$ from furrow bed. The following four treatments were assigned in the experiment.

$\mathrm{T}_{1}=$ Irrigation in raised bed with two rows of rice (RBI two rows),

$\mathrm{T}_{2}=$ Irrigation in raised bed with three rows of rice (RBI three rows),

$\mathrm{T}_{3}=$ Alternate wetting and drying irrigation (AWD),

$\mathrm{T}_{4}=$ Flood irrigation $(\mathrm{FI})$,

Irrigation was applied to the flood irrigation plot at a depth of $5 \mathrm{~cm}$ at each time while water just was disappeared from the soil surface but water content was still above field capacity. Water in AWD irrigation plot was applied when water went down to $10 \mathrm{~cm}$ below the soil surface as measured in the pipes. In raised bed plot, irrigation was applied when water was about to disappear from the furrow beds. Usual management practices like fertilizer application and intercultural operations were done equally throughout the growing season in all treatment plots and the yield characteristics were compared with respect to the yield attained from AWD and flood irrigation.

\section{Results And Discussions}

The grain and biomass yield of Boro rice for different irrigation methods are given in Table 1. The highest grain yield was obtained in treatment $T_{3}(5.09 \mathrm{t} / \mathrm{ha}$ ) where alternate wetting and drying (AWD) irrigation was applied followed by treatment $\mathrm{T}_{4}(4.77 \mathrm{t} / \mathrm{ha})$ where flood irrigation (FI) was applied and treatment $\mathrm{T}_{1}(4.69$ $\mathrm{t} / \mathrm{ha}$ ) where raised bed irrigation in two rows (RBI two rows) was applied, and the lowest grain yield was obtained in treatment $T_{2}(3.91 \mathrm{t} / \mathrm{ha}$ ) where raised bed irrigation in three rows (RBI three rows) was applied. However, the differences in grain yield between the treatment means were statistically insignificant. On the other hand, the differences between the treatment means in biomass production were statistically significant. The highest biomass was produced in treatment $T_{3}$ (AWD) $(4.02 \mathrm{t} / \mathrm{ha})$ where the highest grain yield $(5.09 \mathrm{t} / \mathrm{ha})$ was also produced. Similar trends were observed by other treatments in case of grain and biomass production. Same sequential pattern such as $T_{3}>T_{4}>T_{1}>T_{2}$ was followed by both grain and biomass yield. But a different trend was observed in case of grain-biomass ratio $\left(T_{1}>T_{2}>T_{3}>T_{4}\right)$. The highest grain-biomass ratio was obtained from treatment $T_{1}$ (RBI two rows) followed by treatment $T_{2}$ (RBI three rows) and treatment $T_{3}$ (AWD), and the lowest grain-biomass ratio was obtained from treatment $\mathrm{T}_{4}$ where flood irrigation (FI) was applied.

TABLE 1. Grain and biomass yield of Boro rice (BR 45) as influenced by irrigation methods

\begin{tabular}{|l|c|c|c|}
\hline Treatment & Grain yield (t/ha) & Straw yield (t/ha) & Grain biomass ratio \\
\hline $\mathrm{T}_{1}$ & 4.69 & $3.55 \mathrm{ab}$ & 1.33 \\
\hline $\mathrm{T}_{2}$ & 3.91 & $2.97 \mathrm{~b}$ & 1.30 \\
\hline $\mathrm{T}_{3}$ & 5.09 & $4.02 \mathrm{a}$ & 1.27 \\
\hline $\mathrm{T}_{4}$ & 4.77 & $3.80 \mathrm{ab}$ & 1.26 \\
\hline LSD (at 5\%) & $1.89(\mathrm{~ns})$ & 0.83 & $0.41(\mathrm{~ns})$ \\
\hline
\end{tabular}

The amounts of water applied from irrigation and rainfall together with their productivity for both grain and biomass are given in Table 2. The total rainfall during the growing period was monitored $187 \mathrm{~mm}$. The highest amount of water $\left(1168 \mathrm{~mm}\right.$ ) was applied to treatment $\mathrm{T}_{4}$ (FI) followed by treatment $\mathrm{T}_{3}$ (AWD) (1044 $\mathrm{mm}$ ). The lowest amount of water $\left(670.3 \mathrm{~mm}\right.$ ) was applied to treatment $T_{2}$ (RBI three rows) followed by 
treatment $T_{1}$ (RBI two rows) $\left(706.2 \mathrm{~mm}\right.$ ). The smallest amount of water was applied to treatment $T_{2}$ (RBI three rows) than the treatment $T_{1}$ (RBI two rows) as there were less furrows in treatment $T_{2}$ than the treatment $T_{1}$.

The highest water productivity $(66.41 \mathrm{~kg} / \mathrm{ha}-\mathrm{cm})$ for rice grain was observed in treatment $\mathrm{T}_{1}$ (RBI two rows) followed by treatment $T_{2}(58.33 \mathrm{~kg} / \mathrm{ha}-\mathrm{cm}), \mathrm{T}_{3}(48.77 \mathrm{~kg} / \mathrm{ha}-\mathrm{cm})$ and $\mathrm{T}_{4}(40.86 \mathrm{~kg} / \mathrm{ha}-\mathrm{cm})$. However, a gradually decreasing trend of water productivity for grain yield was noticed clearly. Similar trend of decreasing water productivity was also observed for biomass yield with the highest productivity in treatment $T_{1}(50.88$ $\mathrm{kg} / \mathrm{ha}-\mathrm{cm})$ and the lowest in treatment $\mathrm{T}_{4}(33.70 \mathrm{~kg} / \mathrm{ha}-\mathrm{cm})$. Thus the water productivity for both grain and biomass yield followed a similar trend as $\mathrm{T}_{1}>\mathrm{T}_{2}>\mathrm{T}_{3}>\mathrm{T}_{4}$. This revealed the fact that flood irrigation is less efficient in water use than the other three methods and furrow irrigation in raised bed with two rows of plant is the most efficient one. Increased water productivity by raised bed furrow irrigation in Boro rice over flood irrigation was also reported by other researchers [12].

TABLE 2. Total water applied and water productivity for grain and biomass as influenced by irrigation methods

\begin{tabular}{|c|c|c|c|c|c|}
\hline Treatment & $\begin{array}{c}\text { Irrigation } \\
\text { water }(\mathrm{I}) \\
(\mathrm{mm})\end{array}$ & $\begin{array}{c}\text { Rain water } \\
(\mathrm{R})(\mathrm{mm})\end{array}$ & $\begin{array}{c}\text { Total water } \\
\text { applied }(\mathrm{I}+\mathrm{R}) \\
(\mathrm{mm})\end{array}$ & $\begin{array}{c}\text { Water productivity for grain } \\
(\mathrm{kg} / \mathrm{ha}-\mathrm{cm})\end{array}$ & $\begin{array}{c}\text { Water productivity } \\
\text { for biomass } \\
(\mathrm{kg} / \mathrm{ha}-\mathrm{cm})\end{array}$ \\
\hline $\mathrm{T}_{1}$ & 519.2 & 187 & 706.2 & 66.41 & 50.88 \\
\hline $\mathrm{T}_{2}$ & 483.3 & 187 & 670.3 & 58.33 & 40.49 \\
\hline $\mathrm{T}_{3}$ & 856.7 & 187 & 1043.7 & 48.77 & 38.63 \\
\hline $\mathrm{T}_{4}$ & 980.5 & 187 & 1167.5 & 40.86 & 33.70 \\
\hline
\end{tabular}

Fig.1 shows the water requirement for producing one kilogram of rice grain and biomass for different irrigation methods. The lowest water requirement $(15561 / \mathrm{kg})$ was found for irrigation in raised bed two rows $\left(T_{1}\right)$ while the highest water requirement $(2341 \mathrm{l} / \mathrm{kg})$ was found for flood irrigation $\left(T_{4}\right)$. It indicates that furrow irrigation in raised bed two rows method is the most efficient one although total water applied to raised bed two rows plot $(706.2 \mathrm{~mm})$ was higher than the water applied in raised bed three rows plot $(670.3 \mathrm{~mm})$ (Table 2). This was because of the total yield in raised bed two rows plot (4.69 t/ha) was higher then the yield in raised bed three rows plot $(3.91 \mathrm{t} / \mathrm{ha})$ although the yield differences were not statistically significant. The water requirement for treatment $T_{4}$ where irrigation applied adopting alternate wetting and drying (AWD) method was $2063 \mathrm{l} / \mathrm{kg}$ which was higher than both raised bed two rows $(1556 \mathrm{l} / \mathrm{kg})$ and raised bed three rows $(1819 \mathrm{l} / \mathrm{kg})$ but lower than the flood irrigation method $(2341 \mathrm{l} / \mathrm{kg}$ ) despite its highest yield of $5.09 \mathrm{t} / \mathrm{ha}$ (Table 1). Similar results were observed in an experiment where water requirement for furrow irrigation in raised bed three rows and flood irrigation method were 2083 and 2703 liters per $\mathrm{kg}$ of rice grain, respectively [13]. From treatments $\mathrm{T}_{1}$ and $\mathrm{T}_{4}$ it is revealed that about $50 \%$ less water was required in treatment $\mathrm{T}_{1}$ (RBI two rows) over treatment $\mathrm{T}_{4}(\mathrm{FI})$. This implied that $50 \%$ water can be saved in planting Boro rice in raised bed method. A similar result was also reported by other researchers [14].

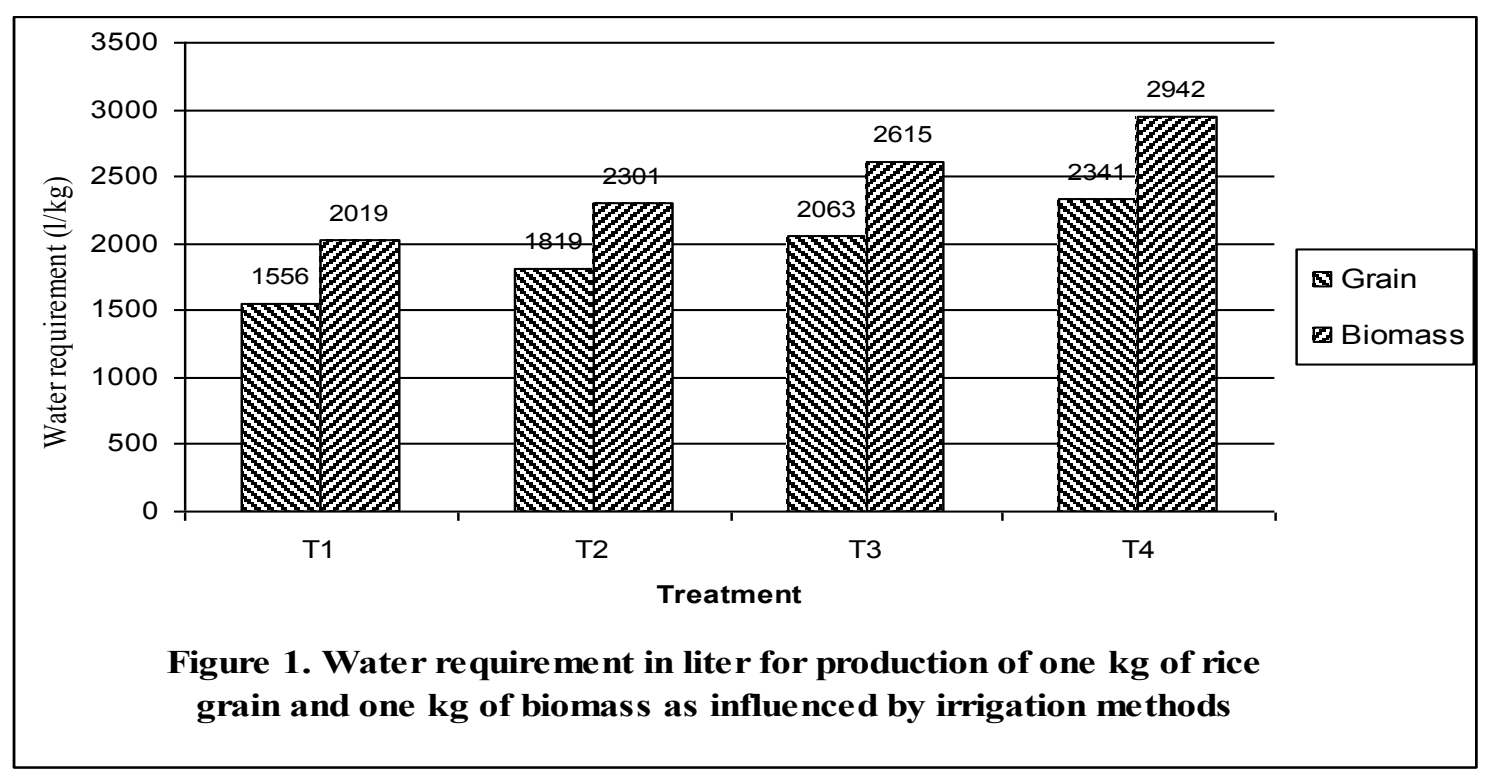

Similar trend was also observed for biomass production (Fig. 1). The lowest water requirement of 2019 liters per kg of biomass was found for treatment $T_{1}$ (RBI two rows) while the highest water requirement of 2942 
liter per $\mathrm{kg}$ of biomass was found for treatment $\mathrm{T}_{4}(\mathrm{FI})$. Thus, it was revealed that the water requirement in treatment $\mathrm{T}_{1}, \mathrm{~T}_{2}$ and $\mathrm{T}_{3}$ were reduced by $34 \%, 22 \%$ and $12 \%$ respectively, over flood irrigation $\left(\mathrm{T}_{4}\right)$.

\section{Conclusion}

On the basis of the aforesaid results and discussion it is apparent that the irrigation methods have significant influence on water requirement for producing Boro rice. Furrow irrigation in raised bed required the least amount of water while flood irrigation required the highest amount of water. This indicates that flood irrigation required more water for producing the same yield of Boro rice. Because of less water used, the water productivity was the highest in raised bed irrigation system for both grain $(66.41 \mathrm{~kg} / \mathrm{ha}-\mathrm{cm})$ and biomass $(58.88$ $\mathrm{kg} / \mathrm{ha}-\mathrm{cm}$ ). Thus raised bed irrigation can save about $22-34 \%$ irrigation water over flood irrigation. Hence, raised bed irrigation can be adopted for Boro rice in those areas where water scarcity is a major problem. However, it would require more labors for raising beds which could be minimized using mechanical aids.

\section{References}

[1] F. R. Rijsberman, Water scarcity: fact or fiction, Agric. Water Management. 80, 2006, 5-22.

[2] J. P. DeCarvalho. 2013. Arsenic poisoning in Bangladesh. (available at www.toxipedia. org/ display/ toxipedia/ Arsenic+ Poisoning+in+Bangladesh, Retrieved on 27July, 2013).

[3] UNICEF. 2008. Arsenic Mitigation in Bangladesh. (available at http:// www. Unicef.org/ Bangladesh/ Arsenic.pdf, updated 12 October, 2008, retrieved on 23July, 2012).

[4] Anonymous. 2010. AWD irrigation technology can benefit Bangladesh. (Available at http:// www.bssnews.net/news Details.php? $\underline{c a t}=$ o\&id $=9069 \&$ date $=2010-02-22$, Retrieved on 23 July, 2012)

[5] M. M. Husain, M. H. Kabir, On-farm experience with AWD for reduced cost, enhanced yield and environment safely. Proc. National workshop on AWD technology for rice production in Bangladesh, 15 July, 2009:15-20.

[6] V. P. Pandey, B. Singh and H. P. Tripathi, Planting of crops with Furrow Irrigated raised bed (FIRB) system and Advantaged of raised bed planting (RBP) in crop production. (Available at http://krishisewa.com/articles/2012/furrow.html, Retrieved on 23July, 2012).

[7] M. I. U. Mollah, M. S. U Bhuiya, M. H. Kabir, S. M. A. Hossain and A. Saha, Evaluation of transplant Aman rice on raised bed in rice - wheat cropping sequence. Bangladesh Rice Journal. 14(1\&2, 2009a, 127-132.

[8] D. E. Van Cooten, and A. K. Borrell, Growing rice on raised beds. (available at http://www.fao.org/prods/gap/database/gap/ files 595 RICE ON RAISED BED IN INDONESIA.PDF, Retrieved on 23July, 2012).

[9] B. W. Dunn, S. K. Mathews, H. G Beecher, J. A. Thompson, and E. Humphreys, 2004. Growing rice on raised beds in southeast Australia. (Available at http://www.cropscience.org.au/ icsc2004/poster /1/2/705dunna.hlm, Retrieved on 23 July, 2012).

[10] U. P. Singh, Y. Singh, H. P. Singh and R. K. Gupta, Performance of permanent raised bed planting in rice-wheat system in Eastern Uttar Pradesh, India. Department of Agronomy, Institute of Agricultural Science, Banaras Hindu University, Varanasi221005, India. (available at http://aciar.Govau//files/ node/14068/ Performance_of_permanent_raised_bed_planting_in_ri_ 96387.pdf, Retrieved on 5 August, 2012).

[11] M. A. Sattar, M. A. Rashid, M. N. Hossain, H. R. Molla, A. K. Khan, S. Parveen, D. Roy, and H. Mahamud, AWD technology for water saving in Boro rice production for the selected locations. Proc. National workshop on AWD technology for rice production in Bangladesh, 15 July.2009: 1-14 pp.

[12] M. N. Hassan, M. A. Khair, A. F. M. Saleh and L. R. Khan, Raised bed furrow irrigation for wheat and Boro rice cultivation in shallow tubewell irrigation project. Bangladesh Rice Journal. 14 (1\&2), 2009, 153-159.

[13] M. J. Islam and M. A. Ghani, Impact of furrow irrigation on rice production. Bangladesh Rice Journal. 1(1), 1990, $32-36$.

[14] M. I. U. Mollah, M. S. U. Bhuiya, A, .Khatun, M. H. Kabir, M. S. Ali, A. S. Khan, Bed planting: A water saving technology in rice-wheat cropping system. Bangladesh Rice Journal. 14(1\&2), 2009b, 139-146. 